\title{
Tea as Nation Builder Pre-Confederation Canada
}

\author{
AUTHOR: Nicole Labrie \\ EDITED BY: Marshall Cosens, Julian Matheson, and Marisa Coulton
}

In the late-eighteenth and early-nineteenth centuries, there was a push to settle the large, 'empty' land that would become known as Canada. ${ }^{1}$ Colonists from France and England journeyed west, and set up settlements along major waterways, like the Saint Lawrence River. Interacting with local populations, colonists realised that there was money to be made in this new land. Trading furs for cloth, alcohol, and various other sundries created a market society in which inhabitants of all classes, races and genders took part. Historian Ann Smart Martin calls the idea of buying commodities to create a place in one's society "buying into the world of goods." 2 People were eager to validate their lifestyles with goods that ranged from the familiar to the new and exotic. Applying Martin's concept of market society to the expansion of settler colonialism reveals the demand for consumer products. New settlers, and their native counterparts, used a burgeoning market society to validate their styles of living, the ties linking their new home and their motherland, and the networks they created throughout their lives. A principal commodity in Canada's history, prenationhood, was tea. Imported by Britain through the East India Company, and distributed throughout the northlands by the Hudson's Bay Company and others, tea was a staple in the average Canadian's diet. Drinking tea was seen as a political statement through its ties to Britain in many parts of Anglophone Canada. The methods people used to consume tea denoted a measure of class as well as formed divisions based along gender roles. The Canadian market society also marked interactions with Indigenous peoples, as well as non-European immigrants. However, it must be acknowledged that outside of European settlements, not much is known about others' methods of consumer culture in pre-Confederation Canada. Primarily, sources are based on interactions with Americans along the east coast. The trade and consumption of tea stretched across Canada by the time of Confederation in 1867. The different regions joining the new dominion experienced the Canadian market economy in a variety of ways. As one of the primary non-alcoholic beverages, tea can be considered a nation-building product, establishing a Canadian identity while reinforcing ties to its sovereign and the Commonwealth.

The primary method for the import of tea into Upper and Lower Canada - Ontario and Quebec, respectively - before Confederation, was through Britain's East India Company (EIC). Established in 1600, the EIC traded primarily in the East Indies, and moved into China in the late seventeenth century; traders with the EIC were only allowed to trade out of Canton. ${ }^{3}$ This exclusive system lasted until the 1830s when the Company lost their monopoly on Chinese trade. ${ }^{4}$ Until then, the EIC was the only company legally allowed to import goods into Britain, which were then distributed in North America. To retain the EIC monopoly in the North American colonies, British Parliament passed a law under the Trade and Navigation Acts in 1763 which prohibited any other trading companies from importing tea into the British colonies. ${ }^{5}$ This allowed Britain to build its strength in their new territory, bringing roughly two-hundred thousand pounds of tea per year into North America; this number was the peak amount for the collective British colonies until the American Revolution. ${ }^{6}$ After the American 
Revolution, tea would enter the United States through various other importers. This would allow for more competition in the United States, and the growth of their market economy. The Revolution allowed for a focus on local goods: furs, local metals, and plantation crops, such as sugar and tobacco. ${ }^{7}$ Purchasing from local producers was not only unique to the United States. British and French settlements in Eastern Canada also thrived on locally sourced goods, along with imported wares from the EIC. Historian Béatrice Craig describes these new, local markets as "engines of growth and development."8 Local markets were helped peripherally by the EIC and their network of merchants in the populated areas of Upper and Lower Canada. However, they came to rely heavily on Canada's own trading company, the Hudson's Bay Company (HBC), for obtaining and selling non-imported goods in the interior where EIC trade routes were not as prominent.

The HBC worked in partnership with the EIC to funnel East Indian and Asian goods through Rupert's Land. Due to the EIC's monopoly on Chinese tea, the HBC was not permitted to trade directly with China; instead, the HBC traded primarily furs to British merchants in Boston in exchange for Chinese goods, such as tea and silk. ${ }^{9}$ However, post-American Revolution, when the United States forfeited their ties with the EIC, the HBC brokered a trade agreement with the American company, Perkins and Company. The British Parliament recognised the benefit in allowing the $\mathrm{HBC}$ to trade with the United States, and so, the two companies traded beaver pelts and Chinese goods over the border without disturbing the British monopoly on Chinese trade. ${ }^{10}$ The HBC also facilitated the sale of tea across the country. Traders took well-established HBC trade routes from ports on the Saint Lawrence River through the Canadian interior to get tea into British Columbia, and to the company's holdings on Vancouver Island. ${ }^{11}$

Traders would stop at well-maintained trading posts along the way, delivering goods to be sold in backcountry general stores where merchants acted as a link to the far-flung British empire. These backcountry stores helped to perpetuate the "capitalist penetration of the countryside," or the exposure of rural people to a new world of consumer goods. ${ }^{12}$ Merchants such as John Hook in Virginia, or John Emmerson in the Madawaska Valley, built these stores to enable rural populations to buy goods regularly. ${ }^{13}$ With access to a general store, people were not only guaranteed stocked shelves, but access to material goods that could be considered "wants" rather than "needs." Merchants were promoters of material culture, influencing trends and boosting market activity, for their benefit, as well as the benefit of the population they served. ${ }^{14}$ When considering how tea affected the market in early Canadian history, it is necessary to think of these backwoods markets, and how the sale of tea impacted the daily lives, and politics, of settlers. Backcountry merchants and general stores were essential to the daily lives of settlers, and for propagating tea to consumers as a dietary staple.

Tea was a staple in the diets of early settlers. It was not inexpensive: one source describes the price of tea as being between seven and nine shillings a pound (roughly $\$ 1.40$ to $\$ 1.80) .{ }^{15}$ In John Hook's Virginian stores, in 1771, he sold over three British pounds worth of tea to eager consumers. ${ }^{16}$ The desire for tea was apparent throughout British North America, and general stores took advantage of settlers' newfound affinity for caffeinated beverages. Historian Béatrice Craig suggests the average adult consumed two ounces of tea per week, or the equivalent of about six modern tea bags. ${ }^{17}$ Rural consumers were likely conscious about their tea intake, and stretched their daily supplies to last as long as possible. Tea was present at nearly every meal: from the breakfast table, served with porridge for poorer families, or meat and eggs for those who were of higher social status, and throughout the day. ${ }^{18}$

Tea was Canada's favourite non-alcoholic beverage into the twentieth century, and accounted 
for the majority of general store accounts lists. Typically bought alongside tobacco, tea was accounted for in 1900 grocery purchases in Upper Canada in the mid-1800s. ${ }^{19}$ Those who bought tea usually bought in smaller quantities, as shoppers then preferred to take trips to the store often in order to obtain fresh goods, but there were instances of tea being bought in bulk. Labourers who worked far from home often bought tea in large quantities as they were unable to make frequent trips to the store. For example, David Rose, a lumberer in Ontario, bought sixty pounds of tea to take into the woods to provide a sense of comfort during long work rotations. ${ }^{20}$ The beverage quickly became commonplace throughout North America. Tea came in different variations to appeal to every class of consumer. John Hook's stores sold finely-made, high-grade teas alongside cheaper versions. ${ }^{21}$ The attraction of tea was not in its grade, but rather the sense of warmth and comfort that the drink imbued. Moreover, tea brought a sense of exoticism that came from consuming a product from a country beyond the average settler's imagination. The scent, texture and taste of tea provided a break from the monotonous rigors of rural farming life, taking the drinker on a sensory journey. The feeling of pleasure experienced drinking tea enticed the settlers to purchase more in the future.

Economic improvements did not erase social class structures in Lower Canada, but rather enforced them, and brought the Francophone population in line with Anglophones. In English and French settlements, tea was a highly prized addition to one's diet. Montreal-based consumers bought tea and cane sugar in equal amounts. People across the economic spectrum were willing to pay higher prices to guarantee the quality of a product that was quickly becoming a staple. Despite a person's economic status, tea was required to be of high quality. ${ }^{22}$ Good quality tea was considered the highlight of the francophone mealtime, where one could expect pork, dried peas and bread, along with some sort of alcohol. ${ }^{23}$ "A cup of tea converted a cold meal into something like a hot one, and gave comfort and cheer," a saying which can apply to all areas of the country, but is especially appropriate for Lower Canada. ${ }^{24}$ The rise of the lumber industry in 1810 provided a new, stable economy. The declining fur trade and new lumber economy led to a prolonged period of prosperity and the development of a market society. No longer trading based on social hierarchy, Francophones began networking on a horizontal level, opening up new methods of transaction and connection. ${ }^{25}$ The standard of living improved for all members of society in Lower Canada, from the rural habitants to city-dwelling labourers, with real income increasing twofold. ${ }^{26}$ The major increase in wages and improved lifestyle allowed merchants to bring in goods like tea. Merchants were able to stock their stores with tea to satisfy the whims of material culture in Lower Canada, which allowed the population to purchase goods that had previously been out of reach.

The affinity for tea and sugar was not confined to Lower Canada, but was universal throughout Canada's settlements. Everyone, it seemed, had a sweet tooth for imported refined sugar, though the market for local maple sugar remained strong as well. ${ }^{27}$ Looking at shopping records, deeds and wills, one can see how tea fit into social hierarchy in both French- and Englishspeaking communities. When those on the lowest end of the social hierarchy, such as low-class workers and farmers, were able to gain access to the market system, they were able to include imported goods in small amounts. Principal grocery items became a mixture of local and imported goods. ${ }^{28}$ Tea was considered a luxury product to people in Montreal; however, that did not stop tea from becoming a necessity to improve the average canal worker's limited menu. ${ }^{29}$ The accessibility of tea over time did not lessen its attractiveness for those who belonged to the upper class. Upper class citizens could afford higher quality products. Likewise, they were able to purchase tea paraphernalia to set them apart from their lowerclass counterparts. Owning a tea set was neither a necessity nor a logical choice. Yet, a tea set lent a sense of ownership and pride to the buyer, and allowed the purchaser a physical manifestation of 
their wealth. ${ }^{30}$ Mary W. Papineau, a merchant's daughter from Montreal, was bequeathed a tea set by her mother that was made of silver, and came with a cake basket, sugar tongs, engraved tablespoons and teaspoons, as well as twelve giltedged plates to use during tea time. ${ }^{31}$ Mary was not the wealthiest, but her family had enough money to buy a fairly extravagant tea set, which suggests they would have been able to buy different types of tea to serve with it. The respectability that came from owning tea sets, and different qualities and types of tea, reinforced familial social status. ${ }^{32}$

Furthermore, the social status was reflected in the gender roles surrounding tea drinking, as women tended to take on the role of social negotiator through planning tea parties and other social events. Five o'clock tea time became a prized tradition in Canada's western colonies. Women in 1860s Victoria, British Columbia, enjoyed exhibiting the wealth and respectability of their families through inviting guests for tea, delicate nibbles, and gossip. ${ }^{33}$ Taking tea in the early evening became a British tradition after Anna, the seventh duchess of Bedford, England reportedly experienced a "sinking feeling," and would enjoy a sampling of tea and biscuits in order to overcome the negative energy. ${ }^{34}$ Settlers from Britain, and Loyalists from the fractured United States, brought the tradition of five o'clock tea with them upon immigrating to Canada. The tradition of tea time was exploited by wealthy women in Canadian high society. Social norms in Victoria, British Columbia ran parallel to that of Victorian England, and centred around hierarchical structures of socialization. ${ }^{35}$ Elizabeth Simcoe, the wife of Upper Canada's first lieutenantgovernor, described a typical high society tea in her diary. It included three different types of brewed tea - green, black, and Russian - as well as cakes and small sandwiches, designed to be eaten delicately as the women participated "in a narcissistic display of availability." 36

Tea parties were not limited to women. Head officers with the HBC often organised gettogethers around the premise of taking tea. Dr. John
S. Helmcken, the main HBC surgeon in Victoria in the 1850s, enjoyed holding tea parties. His parties were so popular, and thrown so often, that his many guests were well aware of the doctor's fondness for tea and sugar. ${ }^{37}$ On August 15, 1837, Abraham Joseph, the son of a prominent Lower Canadian merchant, organised a tea party that featured guests dining on tea cakes, raisins and almonds as they sat on shaded riverbanks; it was a small affair, but one that Abraham took pride in putting together. ${ }^{38}$ Tea parties that were organised by men served a similar purpose as those organised by women. They were highly exclusive social events where guests were expected to network and create business connections, as well as enjoy tea and revelries.

Holidays were also known to be popular times to hold parties where tea was a focal point. One contemporaneous author, Susannah Moodie, described the feeling of participating in her first Canadian New Year's party as being one of excitement, but also exhaustion: "You must keep open house that day, and be dressed up to receive all who choose to come and eat cake and drink wine, tea or coffee with you." 39 Serving tea at large parties was custom in Canadian high society, and everyone was welcome to participate. However, not all meals involving tea were exciting, or even a social activity. Five o'clock tea time soon came to define mealtime for many Canadians. Small, intimate get-togethers centred around food and tea were popular amongst families. John Wells, an English immigrant living in Toronto, often scorned spending time with his friends on Sunday evenings as he preferred to take his tea at that time. ${ }^{40}$ The concept of 'tea' as an important meal of the day, or the most family-oriented meal, for Anglo-Canadians is linked to British tea culture. The meal presented on Canadian dinner tables was often a reproduction of what might be on the table in London, England: fish, vegetables, with a variety of grains and other meats, as well as tea to wash it down. ${ }^{41}$

As consumers of tea, men and women differed. Though tea has been seen historically as a 
feminine drink, it is clear that both men and women enjoyed drinking it. Tea is a prominent feature in the daily lives of both genders. It is interesting to see how tea appeared through a masculine lens. Eighteenth-century Scottish travel writer, Patrick Campbell, mentions tea in his diaries as being an indispensable part of his daily menu, and in the diets of hard labourers. ${ }^{42}$ Tea was very much present in men-only areas such as the shanty towns that served lumberers. It was bought in bulk, and was a revered part of a normally bland mealtime, as those living in the shanty towns did not have the same diets as local farmers. ${ }^{43}$ As indicated by a lumberman from Bobcaygeon, Ontario: "We never seen a pie, we never seen a cookie. Nothin' sweet but blackstrap (molasses). But the tea they biled (sic) in the kittles (sic)- it was real good." ${ }^{4}$ Since labourers often bought tea in bulk, it is interesting to note that this did not drive up local prices as bulk buying placed strain on the importers to obtain more stock.

It is also interesting to note how the presence of tea in Canadian history affected the Indigenous people. In the Madawaska Valley, European settlers mingled with Indigenous people to strengthen local trade, and worked with Indigenous traders to attain goods such as moccasins to market. ${ }^{45}$ The Innu people of the Maritimes and northern regions of Lower Canada were fond of black tea, and developed a unique way of transporting it with them on their travels: by using it to stuff dolls. The Innu tea doll was made of fabric, often caribou hide, and was stuffed with loose tea. ${ }^{46}$ When the tea ran out, children would re-stuff the doll with grass to maintain the shape. Tea was important to Indigenous people in the interior of Canada as a trade commodity with the HBC. Tea from the HBC was frequently of high quality, and given as gifts to Indigenous traders. When Governor Simpson was placed in charge of restructuring the HBC in 1821, he wanted to stop the giving of gifts. The backlash from Indigenous clients, who valued exchanging gifts as a measure of goodwill, was so great that he ultimately conceded to allow the custom of giftgiving. ${ }^{47}$ William Johnson, a prominent trader on the eastern Great Lakes of North America, also described giving tea as gifts to the Mohawk People. It can be inferred that he featured this drink at his table when he held treaty conferences as Johnson used both European and Indigenous material goods to create an appearance that would appeal to both sets of traders. ${ }^{48} \mathrm{As}$ a gift, tea was indispensable to the Indigenous people. Along with bannock, it was a staple in the frontier settlers' pantry, and held up well on treks through the bush. ${ }^{49}$

The gold rush in 1858 witnessed an influx of Chinese immigrants to Western Canada. In 1860, the Victoria Daily Colonist reported that approximately four-thousand Chinese immigrants arrived to work in the gold fields. ${ }^{50}$ Tea was important in the diet of these new immigrants, and importers sought to meet rising demands for tea products. As the EIC lost their monopoly on the Chinese tea trade in 1834, the West Coast became a hub for American, British, and now Chinese merchants. ${ }^{51}$ The importing firm, 'Kwong Lee,' was established in Victoria and brokered trade deals with the Chinese immigrants working in the gold fields. So many people were working in the gold fields that small, "pop-up" communities were established to cater to any needs that the workers might have. Markets, laundries, and other essential services followed the workers to serve the growing labour population. The largest of these pop-up towns was Barkerville, which was "the largest [Chinese] community north of San Francisco and West of Chicago" in $1862 .{ }^{52}$ The community relied on importers like Kwong Lee to supply them with goods from China, including tea, that were difficult to acquire locally. Sources regarding how non-Europeans interacted with tea, and created their own tea culture, are much rarer when looking into Canada's pre-Confederation history; however, it is clear that tea did play a role in the interaction with, and daily lives, of nonEuropeans.

Much can be said about how tea affected the growth of Canada, pre-nationhood, but it is interesting when viewed as a nation-building tool. Tea was not exclusive to any one population in 
Canada but was enjoyed by people across the land. It was propagated by British, American, and Chinese traders, and encouraged communities to take part in local economies. Tea played a role in connecting and trading with Indigenous populations who contributed to the expansion of trade routes across the interior. Tea-drinkers became arbiters of personal taste, and strengthened a burgeoning market economy. As the country progressed into the late-nineteenth century, tea became less of a prized exotic commodity; what was once allocated to the wealthy settlers was being enjoyed by everyone. The consumption of tea was not done uniformly. The trend did not necessarily trickle down the social hierarchy, but rather, it gained new life and significance on every level of the social strata. From the backwoods of the Madawaska Valley to the high-society parlours of Victoria, tea culture was shaped to personal taste and heritage.

\section{ENDNOTES:}

1. I will be using the term "Canada" throughout this essay for ease of definition.

2. Ann Smart Martin, Buying into the World of Goods (Baltimore: The Johns Hopkins University Press, 2008), 1.

3. "China Trade and the East India Company," The British Library, accessed December 2, 2017, http://www.bl.uk/reshelp/findhelpregion/asia/china/ guidesources/chinatrade/index.html.

4. Sydney Cunliffe, "British Imperialism and Tea Culture in Asia and North America, 1650-1950," Master's thesis (University of Victoria, Victoria, 2014), 5.

5. John Styles and Amanda Vickey, eds., Gender, Taste, and Material Culture in Britain and North America 1700-1830 (New Haven, CT: Yale University Press, 2006), 235.

6. Cunliffe, "British Imperialism," 22.

7. Martin, Buying into the World of Goods, 5.

8. Béatrice Craig, Backwoods Consumers and Homespun Capitalists: The Rise of a Market Culture in Eastern Canada (Toronto: University of Toronto Press, 2009), 4, eBook Academic Collection (Ebscohost), accessed November 23, 2017.

9. Cunliffe, "British Imperialism," 9.

10. Ibid.
11. Ibid, 76 .

12. Craig, Backwoods Consumers, 113.

13. Martin, World of Goods, 14.

14. Craig, Backwoods Consumers, 114.

15. Douglas McCalla, "A World Without Chocolate:

Grocery Purchases at Some Upper Canadian

Country Stores, 1808-1861," Agriculture History

79 (2005): 172, footnote 20. http://www.jstor.org/ stable/3745048

16. Martin, World of Goods, 83.

17. Craig, Backwoods Consumers, 244.

18. Dorothy Duncan, Canadians at the Table: Food, Fellowship, and Folklore: a Culinary History of

Canada (Toronto, ON: Dundurn Press, 2006), 69.

19. McCalla, "A World Without Chocolate," 154.

20. Ibid.

21. Martin, World of Goods, 171.

22. Donald Fyson, "Du Pain au Madère :

L'alimentation à Montréal au Début du XIX Siècle,"

Revue d'histoire de l'Amérique française, 46 (1992) : 81.

23. Ibid, 82.

24. Ibid, 81.

25. Gilles Paquet and Jean-Pierre Wallot, Lower Canada at the Turn of the Nineteenth Century:

Restructuring and Modernization (Ottawa, ON: The Canadian Historical Association, 1988), 8.

26. Ibid, 6 .

27. McCalla, "A World Without Chocolate," 168.

28. Ibid.

29. Fyson, "Du Pain au Madère," 87.

30. Craig, Backwoods Consumers, 224.

31. Françoise Noël, Family Life and Sociability in Upper and Lower Canada, 1750-1870: A View from Diaries and Family Correspondence (Montreal, QC: MQUP, 2003), 302, footnote 91, eBook Academic Collection (EBSCOhost), EBSCOhost (accessed

December 2, 2017)

32. Cunliffe, "British Imperialism," 92.

33. Ibid.

34. Duncan, Canadians at the Table, 158.

35. Cunliffe, "British Imperialism," 89.

36. Styles and Vickery, Gender, Taste, and Material Culture, 12.

37. Cunliffe, "British Imperialism," 89.

38. Noël, Family Life, 221.

39. Ibid, 212.

40. Ibid, 237. 
41. Fyson, "Du Pain au Madère," 82-83.

42. McCalla, "A World Without Chocolate," 148.

43. Craig, Backwoods Consumers, 179.

44. Duncan, Canadians at the Table, 151.

45. Ibid, 17.

46. "Innu Tea Doll," Twillingate Museum and Craft

Shop, accessed December 3, 2017, http://www. tmacs.ca/cs innu.shtml.

47. Arthur J. Ray, Illustrated History of Canada's Native People, Fourth Edition: I Have Lived Here Since the World Began (Montreal, QC: MQUP, 2016), 164, ProQuest Ebook Central (accessed November 30, 2017).

48. Timothy J. Shannon, "Dressing for Success on the Mohawk Frontier: Hendrick, William Johnson, and the Indian Fashion," The William and Mary Quarterly 53 (1996): 36-37.

49. Ray, Illustrated History, 164.

50. Duncan, Canadians at the Table, 124.

51. Cunliffe, "British Imperialism," 5.

52. Duncan, Canadians at the Table, 124.

\section{BIBLIOGRAPHY:}

"China Trade and the East India Company," The British Library, accessed December 2, 2017, http://www.bl.uk/reshelp/findhelpregion/asia/ china/guidesources/chinatrade/index.html.

"Innu Tea Doll," Twillingate Museum and Craft Shop, accessed December 3, 2017, http://www. tmacs.ca/cs_innu.shtml.

Collard, Elizabeth. Nineteenth-Century Pottery and Porcelain in Canada. Montreal, QC: McGill University Press, 1967.

Craig, Béatrice. Backwoods Consumers and Homespun Capitalists: The Rise of a Market Culture in Eastern Canada. Toronto: University of Toronto Press, 2009. eBook Academic Collection (Ebscohost), accessed November 23, 2017.

Cunliffe, Sydney. "British Imperialism and Tea Culture in Asia and North America, 16501950," Master's thesis. Victoria: University of Victoria, 2014.

Duncan, Dorothy. Canadians at the Table: Food, Fellowship, and Folklore: A Culinary History of Canada. Toronto, ON: Dundurn Press,
2006.

Fyson, Donald. "Du Pain au Madère : L'alimentation à Montréal au Début du XIX Siècle," Revue d'histoire de l'Amérique française, 46 (1992) : 67-90.

Martin, Ann Smart. Buying into the World of Goods. Baltimore: The Johns Hopkins University Press, 2008.

McCalla, Douglas. "A World Without Chocolate: Grocery Purchases at Some Upper Canadian Country Stores, 1808-1861," Agriculture History 79 (2005): 147-172. http://www.jstor.org/stable/3745048.

Noël, Françoise. Family Life and Sociability in Upper and Lower Canada, 1750-1870: A View from Diaries and Family Correspondence. Montreal, QC: MQUP, 2003. eBook Academic Collection (EBSCOhost), EBSCOhost (accessed December 2, 2017)

Paquet, Gilles and Jean-Pierre Wallot, Lower Canada at the Turn of the Nineteenth Century: Restructuring and Modernization. Ottawa, ON: The Canadian Historical Association, 1988.

Ray, Arthur J. Illustrated History of Canada's Native People, Fourth Edition: I Have Lived Here Since the World Began. Montreal, QC: MQUP, 2016. ProQuest Ebook Central (accessed November 30, 2017).

Shannon, Timothy J. "Dressing for Success on the Mohawk Frontier: Hendrick, William Johnson, and the Indian Fashion," The William and Mary Quarterly 53, no. 1 (1996). http://www.jstor.org/stable/2946822.

Styles, John and Amanda Vickey, eds., Gender, Taste, and Material Culture in Britain and North America 1700-1830. New Haven, CT: Yale University Press, 2006. 